\title{
Article
}

\section{What Kind of Agriculture? What Might Science Deliver?}

\author{
Lawrence Busch \\ Professor of Standards and Society, Lancaster University, Institute for Advanced Studies, CESAGEN, Lancaster LA1 4YD, UK
}

\begin{abstract}
À la mission traditionnelle de l'agriculture - produire pour nourrir -, le XXe siècle finissant en a ajouté bien d'autres : l'environnement, l'énergie, la gestion des territoires, la santé des hommes... Toutes ces missions sont-elles compatibles alors que la recherche s'est spécialisée sur des objets et des savoirs de plus en plus fragmentés, et que standards et normes se sont développés et imposés dans le monde entier ? Le potentiel agricole n'étant pas indéfiniment extensible alors que la demande continue de croître et de se diversifier, de nouvelles politiques agricoles s'imposent. Sur la base de quelles connaissances et dans quel objectif ? Il s'agit bien là pour l'auteur d'une question de démocratie technique : entre savoir spécialisé des experts et attentes différenciées des citoyens, il nous propose une méthode itérative fondée sur la mise en discussion de ce que nous voulons pour l'agriculture de demain, sur la mobilisation de nos capacités d'imagination et pas seulement sur les savoirs établis ou censés l'être.
\end{abstract}

La Rédaction

\section{Keywords:}

agriculture; research;

ethics; production; productivity

\section{Mots-clés :} agriculture ; recherche; éthique; production productivité

\begin{abstract}
Until recently, nearly all agricultural research was unified by a focus on increased production. Arguably, production subsidies in Europe and the US made that approach viable. But today, paradoxically, we are faced with both growing fragmentation and integration in agricultural research. Agricultural research is now seen as the solution to problems of global warming, rural development, environmental improvement, economic growth, sustainability, and even public health. We can discern the outlines of a new integration of food, pharmacy, diet, and health. But, at the same time, we can also see a gulf between molecular approaches to biology - genomics, proteomics, metabolomics, among others - and older fields such as systematics, and plant and animal breeding. This is paralleled by a shift from public standards focused largely on safety, to a proliferation of sometimes conflicting standards for sustainability, worker rights, fair trade, and organic, etc. Missing is any attempt to ask what kind of food and agriculture we want. We need to begin to answer this fundamentally ethical question if we are to ensure that investments in agricultural research yield improvements.
\end{abstract}

\begin{abstract}
Résumé - Quel type d'agriculture ? Que pourrait apporter la science? Jusqu'à récemment, un objectif commun unifiait presque entièrement les efforts de la recherche agronomique : accroître la production. Certains problèmes de productivité ont même souvent été occultés au nom de cet accroissement. En Europe et aux États-Unis, cet objectif a été soutenu par des subventions à la production. Mais aujourd'hui, paradoxalement, nous sommes confrontés à une recherche agronomique qui devient à la fois plus fragmentée et plus intégrée. Le secteur public perd la main; c'est le secteur privé qui prévaut presque partout. De plus, les missions de la recherche agronomique ont changé. Si la recherche est soutenue, c'est parce qu'on lui demande d'apporter des solutions aux problèmes de changement climatique, de développement rural et même de santé publique. D'un côté, on constate une intégration nouvelle entre aliments, régime alimentaire et médicaments, tandis que, de l'autre, un fossé considérable et peut-être grandissant se creuse entre les approches moléculaires de la biologie - génomique, protéomique, métabolomique, entre autres - et des domaines plus anciens tels que taxonomie et sélections végétale et animale. Parallèlement, il se produit une transition à partir de normes publiques axées largement sur la sécurité sanitaire des aliments vers une prolifération parfois conflictuelle de normes relatives à la durabilité, aux droits des travailleurs,
\end{abstract}

\footnotetext{
Corresponding author: lbusch@msu.edu

L. Busch is also University Distinguished Professor, Institute for Food and Agricultural standards, Michigan State University, East Lansing, MI 48824, USA.
} 
au commerce équitable, à l'agriculture biologique, etc. Ce qui manque dans tout cela, c'est une tentative de formuler la question : quel genre d'agriculture et d'aliments voulons-nous ? Il nous faut d'abord trouver un début de réponse à cette question essentiellement éthique si nous voulons que les investissements dans la recherche agronomique soient en mesure d'améliorer la situation.

Agricultural research arose in the late 19th century as a means of valorizing colonial empires and reducing the cost of food in the industrialized nations (Brockway, 1979; Brockway, 1988; Osborne, 1982). But nearly the entire 20th century can be viewed as a time of almost obsessive desire to increase agricultural production. Production, through the entire 20th century, remained an undiluted good (McConnell, 1953). Even during the devastating American drought of the 1930s, usually referred to as the Dust Bowl, only a few voices were raised about the obsession with production (Worster, 1979) ${ }^{1}$.

Productivity is usually understood as the ratio of inputs to outputs, either producing more output for the same amount of input or the same amount of output with less input. But while productivity was understood by economists, and to a lesser extent by "economic entomologists", most agricultural scientists remained unconcerned about productivity until late in the 20th century. Indeed, the much vaunted Green Revolution was mostly about increasing production (Perkins, 1997; Shiva, 1991). Moreover, while the initial critics of the Green Revolution rightly challenged it with respect to equity and environmental implications, they rarely challenged the obsession with production ${ }^{2}$.

Today, despite the formation of the World Trade Organization and growing concern about climate change, and the environment more generally, to a considerable degree agricultural exceptionalism reigns. The European Union and the United States still support policies that encourage ever-increasing production and low food prices. Even the recent concern over rising food prices seems only to have caused a minor degree of concern, now rapidly fading into oblivion. In any case, in addition to heavy subsidies, the entire push for production has been and remains dependent on vast quantities of cheap oil (to make agricultural chemicals for pesticides and fertilizers, as well as to run farm equipment), and the considerable exploitation of the environment including often subsidized water prices and unchecked soil erosion.

\footnotetext{
1 This paper is a revised version of a paper presented at a conference on "Sciences en société", Paris, November 2008. The support of the Economic and Social Research Council of the United Kingdom, and the Michigan Agricultural Experiment Station is gratefully acknowledged.

2 Importantly, from early in the century, increased production was coupled with (a usually Malthusian) concern for population control. For an early view, see the volume written by Edward M. East (1923), one of the developers of hybrid maize. In the postwar period this was refined as the so-called "demographic transition" thesis. For an overview, see Szreter (1993).
}

\section{The Changing Landscape of Agricultural Issues}

Furthermore, while in the past the public sector set the agenda for agricultural research, today it is industry that sets the agenda. Industry spends far more than the public sector in most industrial nations ${ }^{3}$. Moreover, industry has become ensconced as an intermediary between public research and farmers, such that many if not most of the products generated by public research stations and universities can only be used by farmers (and certainly by consumers) if further transformed by industry (Wolf and Zilberman, 2001).

Seeds, semen, breeding stock, machines, and agrichemicals are all supplied by small and diminishing numbers of firms (Hendrickson et al., 2001). And at the same time, the number of food processing companies and food retailers is declining (Busch and Bain, 2004). Indeed, one consultant has estimated that the entire European public is dependent upon approximately 110 persons - the buyers for the key supermarket chains (Grievink, 2003). Doubtless, the situation in the United States is little different.

This said, in a peculiar way most publics are no longer happy (solely) with production research. While some large farmers still celebrate increased productivity as a means to make the technology treadmill run faster and increase their market share (Cochrane, 1993), other publics are proposing a range of new agendas. (Or perhaps one should say that the general weakening of the political clout of the agricultural sector, in part due to declines in the number of persons engaged in farming in nearly every industrial nation, is allowing dissenting voices to be heard.) These include:

- Global Warming. It is now apparent that agricultural production plays a role in global warming. Farm animals produce significant quantities of greenhouse gases, and it is even possible that grain-fed confinement operations increase the amount of gas produced per animal (Monteny et al., 2006). Moreover, extensive agriculture threatens to reduce the area in rainforest and lead to further desertification and climate change (Shukla et al., 1990).

- Rural Development. In both the industrialized world and in the poor nations of the world rural development is often touted as a legitimate goal for agriculture

\footnotetext{
${ }^{3}$ In the US, private expenditures for agricultural research surpassed public sector expenditures about 1980 (Caswell and Day-Rubenstein, 2006).
} 
and agricultural research. On the one hand, multifunctionality is in large part a response to the depopulation of the countryside as the scale of agricultural production has increased (Brunstad et al., 2005; Knickel and Renting, 2000). The rapid growth in interest in geographical indicators even more directly sees agriculture as a generator of rural incomes and thereby development. In addition, more radical movements such as Slow Food, promote rural development to enhance local economies while promoting biodiversity (Miele, 2008). On the other hand, the rapid growth in global markets for agricultural products - particularly fruits and vegetables - has brought new demands for research on specialty crops suited to tropical climates, but largely sold in temperate zones (Liu et al., 2001). Each of these approaches are linked to the notion that agricultural production can be a means for increased economic growth. However, producing that economic growth requires (1) a shift in the nature of the crops and livestock that are the subject of research, (2) new methods of production that meet new intermediate and final consumers, or (3) research on new forms and approaches to food processing, or some combination of these.

- Environmental Remediation. For some, agriculture is seen as a potential site for the remediation of various environmental problems (e.g., Comis, 1996; Macek et al., 2000). Hence, safer means for the recycling of human waste on farmland, as well as the use of plants to concentrate and remove heavy metals from soil, offer new avenues for agricultural research as well as new forms of agriculture.

- Sustainability. While still somewhat undefined, growing demands for sustainability (e.g., Thompson and Nardone, 1999) and the so-called triple bottom line (Davis, 2005) directly challenge the older productionoriented research. Put simply, what produces the highest yields is very often unsustainable - economically, ecologically, and socially. The rapid growth in sales of organic produce is but one, albeit flawed, indicator of public concern about sustainability.

- Public Health. Agriculture is also now seen as a site of public health (McMichael and Beaglehole, 2000) ${ }^{4}$. First, dietitians and nutritionists continually extol the benefits of eating larger amounts of fruits and vegetables, and less meat and grain. Such changes in diet would require a massive overhaul of agricultural production in nearly every nation (Lloyd and Cronier, 1989). The research to accomplish such a transformation is scanty at best. Second, overconsumption of highly processed high fat, high carbohydrate foods (e.g., Uauy et al., 2001), as well as larger portion sizes

\footnotetext{
4 The School of Public Health at Johns Hopkins University has even created an "Agriculture and Public Health Gateway." See: http://aphg.jhsph.edu/
}

(e.g., Young and Nestle, 2002), are seen as the culprit behind rising rates of obesity. Addressing these issues would involve a substantial rethinking of the organization of the entire industrial food system.

- Fuels. Finally, the recent rise in oil prices has brought on a search for renewable fuels including those of agricultural origin. At the moment, ethanol from maize is touted in the United States, in large part as a result of heavy subsidies to production and taxes on imported ethanol. Debates continue as to the environmental and economic viability of such fuels (Dale, 2008; Pimentel and Patzek, 2005). Some argue that only lignocellulose feedstocks will produce the desired energy yield (Wheals et al., 1999). Whatever the outcome of the debate, significant sums have been devoted to research to improve their energy efficiency.

Moreover, even as we talk of new goals for agricultural research, we can hardly avoid the now blurred boundaries separating food production, pharmacy, nutritional supplements, and health. Whereas these were four separate sectors until quite recently, they have rapidly come together. A century ago the first enriched foods appeared in the marketplace ${ }^{5}$.

For example, in the United States and Britain white flour enriched with vitamins and minerals (largely removed in milling), became a dietary staple in the form of white pan bread, while the baguette replaced less refined breads in France. Similarly, the 'enrichment' of milk with Vitamin D became commonplace. This blended food production with nutritional supplements. More recently, the advent of pharmafoods and nutraceuticals (Wildman, 2001) have blurred the distinction between food production, pharmacy, and health. Products such as Benecol ${ }^{\mathrm{TM}}$, a cholesterol-lowering margarine, are simultaneously food and medicine.

However, these vast changes - from a singular obsession with production to a profusion of goals for agricultural research, combined with major transformations in the relations among economic sectors - tell only part of the story. Agricultural research itself has been transformed. Let us turn to that side of the story.

\section{The Changing Landscape of Agricultural Research}

Within the scientific community there are growing gaps among the sciences. On the one hand the new molecular sciences of genetics, genomics, proteomics, and metabolomics, among others, are attracting both attention and considerable financial resources (Evans, 2000). They hold the promise of radical transformation of both food

\footnotetext{
${ }^{5}$ For an excellent history of these developments, see Levenstein (1988).
} 
and agriculture. They promise greater harvests for the same inputs, and foods with tailored dietary properties. Virtually every industrial nation and quite a few middle income nations have invested heavily in these fields of research.

At the same time, however, traditional fields of agricultural research have often received short shrift. Systematics has nearly disappeared as a field. Thirty years ago, Jack Harlan (1984) and other systematists were considered central actors in agricultural research ${ }^{6}$. Today, the very term "systematics" has largely faded from most agricultural laboratories and experiment stations. Similarly, in the plant sciences, it was plant breeders who were kings of the hill; those in other plant sciences built on what the breeders suggested. Today, they are relatively rare in public research institutions and they are no longer in such central positions ${ }^{7}$. Much the same could be said of the role of animal breeders in the animal sciences. Some nations, such as the United Kingdom, have gone even further. They have jettisoned most of their public research institutions in their enthusiastic embrace of neoliberalism.

I submit that there are three features that help to create the gulf between the molecular and whole organism approaches in agricultural research: time, space, and precision. Specifically, the molecular sciences tend to compress time and space (Hansen et al., 1986). For example, instead of determining herbicide tolerance by growing whole plants in the greenhouse or field, one can do initial screening by spraying herbicides on Petri dishes with bits of callous tissue in the laboratory. Instead of an entire field or greenhouse, one needs only a laboratory. Instead of an entire season for plant growth, one needs only a few weeks in the laboratory. Moreover, the very fact that the research can be done in the laboratory means that it can be made far more precise; even temperature and light can be precisely measured. Measurements can be more refined as they are made under much more controlled circumstances.

Of course, critics may argue that the compression of time and space and the increased precision come at a cost. Indeed, that is the case. Not a few molecular biologists have been humbled by the fact that what works in the lab, under highly controlled laboratory conditions, is often only weakly correlated with what goes on in the field or greenhouse. Others have discovered that while Arabidopsis thaliana is a convenient model organism with a short reproductive cycle, many crop plants do not neatly conform to the findings of Arabidopsis research. The grandiose

\footnotetext{
6 The barcoding of life project is one attempt to revive systematics. It involves linking it to the growing power of the molecular biological sciences. See, for example, Marshall (2005) and Stoeckle (2003).

7 Few studies have documented the decline in breeding activities. An exception is Frey (1996) which notes significant declines in both the public and private sectors in the US.
}

claims of the mid-1980s have been scaled back somewhat. Indeed, despite several decades of lavish investment in research, most of the promises of agricultural biotechnology remain as yet unfulfilled. And, there has been a realization that even when molecular and whole plant approaches are combined, only a few years can be shaved off of what is a lengthy process of inserting the genes that code for the desired trait into an agronomically viable crop plant. Perhaps this is one reason why the recent International Assessment of Agricultural Knowledge, Science and Technology for Development (IAAKSTD, 2008) has given only lukewarm enthusiasm to molecular approaches to resolving problems of agriculture and food.

Much as there has been a fragmentation of the sciences, and hyperspecialization within the agricultural sciences, there has also been a veritable explosion of standards (Brown and Getz, 2008; Byers et al., 2008; Fulponi, 2006; Guthman, 2007). Let us consider that phenomenon as well as it also has implications for agricultural research.

\section{Standards, Standards, and More Standards}

Retailers, non-governmental organizations, and even governments have been increasing the number of standards demanded of producers and processors. The result is a crazy quilt of standards for everything from food safety to fair trade to organic to rainforest-friendliness to animal welfare to social accountability to corporate social responsibility.

Consider that even within the confines of food safety standards, in addition to national legal requirements, we now find the Codex Alimentarius, the ISO 22000 series, Globalgap, and a host of other retailer- and processordesigned standards. Importantly, many of the standards are arguably meaningless from the perspective of food safety, but are designed with the intention of protecting retailers and processors from unwanted "due diligence" lawsuits ${ }^{8}$.

Most, but not all, of these standards are reflected in logos or short statements of various sorts on food packages. A package of coffee might well have logos reflecting that it has met standards for fair trade, bird friendliness, respect for the environment, and organic production among others. Whether or to what degree consumers pay attention to this information is unclear; perhaps only a small percentage actually care about any given standard. However, given the very narrow profit margins in most agrifood supply chains, even a few extra percentage points might make the difference between profit and loss.

In short, the contemporary paradox is the combination of growing fragmentation and integration at the same

\footnotetext{
8 See, for example, Bain and Busch (2004).
} 
time. Fragmentation is occurring upstream as the molecular sciences become detached from those concerned with what goes on in the field, and downstream as retailers impose an ever-growing range of standards on suppliers. At the same time, integration is increasing as food, agriculture, nutrition, and health become nearly inseparable in the public eye, in corporate marketing units, and in the scientific laboratory.

We are left in a position somewhat similar to that of Alice in Lewis Carroll's Alice in Wonderland:

"Alice. - Would you tell me, please, which way I ought to go from here?"

"Cheshire cat. - That depends a good deal on where you want to get to."

\section{The Missing Pieces}

All of this is related to what might be termed the crisis of representative democracy. While representative democracy emerged out of battles between European aristocrats and kings, and in most instances has led to universal adult suffrage, modern democracies have great difficulty in grappling with the myriad technical objects found in our contemporary world and with the science surrounding them. Voting, whether by the electorate as a whole or by elected legislators seems ill-designed for developing research policy and even less suited for evaluating the products of technoscience. In particular, research policy is rarely if ever a binary decision; it is rarely a matter of simply voting yes or no. Indeed, simplifying it to the extent that a mere yes or no vote can be accomplished may well undermine the decision itself. What is needed, I submit, is an iterative approach.

Perhaps the experts can tell us what to do. This idea was well-articulated by Plato in 360 B.C. (cf. Plato, 1994), and even more carefully spelled out by Francis Bacon (1561-1626). For the latter, the ideal state would be ruled by the House of Salomon, a body of agricultural scientists who would "make (by art) in the same orchards and gardens, trees and flowers to come earlier or later than their seasons; and to come up and bear more speedily than by their natural course they do" (Bacon, 1974, p. 241). Bacon's approach has now been superseded by that used in risk analysis and cost-benefit analysis. Such techniques certainly have their place; we all want to be warned away from dangerous food products and extremely expensive research that is likely to yield little. However, as Bromley (1998) has argued, experts tend to extrapolate based on what was, on the past. We need to base decisions on what kind of future we want.

Another approach is that initially developed by philosopher John Dewey (1927). Dewey noted the publics only come into existence when there are issues to be deliberated (Marres, 2007). While one can certainly ask people to vote, or to participate in a survey on matters of which they know and care little - and even get responses that can be tallied ${ }^{9}$ ! - such actions fail to provide an opportunity for meaningful deliberation. This suggests an urgent need to invent new forms of deliberative democracy through which the concerns of emergent publics can be articulated. Some institutional innovations of this sort have been tried out in various locales: consensus conferences, Internet dialogues, public hearings, focus groups, and others have been employed in an attempt to grapple with this dilemma (Middendorf and Busch, 1997). None are fully satisfactory; doubtless further innovation is desirable.

Dewey's concern resonates well with a notion that has emerged out of research in Science Studies over the last several decades, namely that science and society are co-constructed (Charvolin et al., 2008). From this perspective, we are in error if we believe that scientists merely discover truths about the world that members of society then use to their benefit (or, alas, detriment). Instead, the products of science and engineering provide all of us with new opportunities to act, potential new solutions to old problems, new paths to follow, new profits to seek, new risks to avoid, new dilemmas to face. As a recent report to the European Commission suggests, the promises, truths, and products of science and engineering conceal normative stances as well (Wynne et al., 2007). Ultimately, some of these are found to be "essential" for living, while others are found to be scourges we wish could be banished from the planet, and most are found to have both positive (for some) and negative (for others) consequences associated with them. At the same time, scientists and engineers, like all members of society, attempt to use their physical apparatus and conceptual frameworks to discover new possibilities for action - but often with only the most incoherent forms of guidance from the rest of society.

While it is difficult to discern precisely what forms such institutional innovations might take, one can suggest conditions that such institutions will need to fulfill. First, they need to iteratively determine where we want to go and how we want to get there. Of particular importance here is the word "iterative". It is neither possible nor desirable to develop "the plan" and then to move on to execute it. No matter how carefully we design today's future, tomorrow we will want a (more or less) different one. Hence, any proposed future for research or other activities must be regularly re-examined.

Second, such institutional innovation must involve both experts and publics. Experts can tell us what they believe is or might be feasible, while publics can tell us what they believe they desire. Any future must lie at the juncture of these two.

\footnotetext{
${ }^{9}$ For an odyssey of survey responses, see Lang (1981).
} 
But let us be fair to the experts! Experts are expert about what is or what might be the case. However, expertise comes at a price: specialization. Experts have no special expertise about what should be the case ${ }^{10}$. Nor can they be expected to predict the impact of all new technologies in all the settings in which they might be used. Hence we need to abandon the idea of asking them to do the impossible - to base ethical decisions on expert knowledge.

Let's be fair to the publics as well! Publics have knowledge of the particular circumstances in which they find themselves. These forms of knowledge are not merely different from that of the experts. They often include insights and concerns that are invisible to experts. Only by virtue of being immersed in a particular situation do they even become visible. Indeed, as Dewey suggests, it is those concerns that lead to the rise of publics in the first place. Furthermore, publics may justify their courses of action in multiple, and equally legitimate, ways. Hence, they may appeal to civic responsibility, to the market, to the environment, to religion, to a wide range of justifications for their actions. Each of these justifications is legitimate in certain contexts; the most protracted debates and deliberations occur when these justifications collide (Boltanski and Thévenot, 2006; cf. Walzer, 1983).

We should also remember that the politics of research is like all politics. As Bismarck suggested in far different circumstances, politics is the art of the possible. Politics involves compromises among what are often equally legitimate competing values. In the deliberations that lead to such compromises the experts can tell us what futures might be - perhaps in the plural and with contingencies included as the report to the European Commission suggests (Wynne et al., 2007) - and the publics can tell us what futures they want. Clearly there is a need for more public forums where dialogues of this sort can take place. Such dialogues must, if they are to be effective, be deliberative; they must not be mere bargaining sessions in which each party vigorously maintains its position and tries to negotiate the best possible outcome under the circumstances, as much of the rational choice literature suggests. To the contrary, institutional innovations that bring about deliberation must be - perhaps more than anything else - learning institutions. Put differently, the very act of deliberation can and should lead to new understandings, new paths forward, and even new, previously unimagined futures.

${ }_{10}$ Of course, experts can forecast or predict the outcomes of experiments with more or less accuracy. They can tell us that under the right conditions two parts hydrogen to one part oxygen results in the creation of water. But such forms of prediction are quite different from ethical decisions about desirable futures.

\section{Conclusions}

In sum, the kind of agriculture that we want has to be a kind that science might deliver. But which of the many kinds of science and the many kinds of agriculture that one or more sciences might produce will help us to construct a desired future? Experts and laypersons, in the form of publics, need to deliberate together to construct a future for agriculture and agricultural research. No optimum solution is possible as society is not a mathematical equation to be solved, but a commons to be improved. In the creation of this commons, as Winston Churchill said quite succinctly, "Experts should be on tap, not on top."

\section{References}

Bacon, F., 1974. The Advancement of Learning [1605] and New Atlantis [1626], Oxford, Clarendon Press.

Bain, C., Busch, L., 2004. Standards and Strategies in the Michigan Blueberry Industry. Research Report 585, Michigan Agricultural Experiment Station, East Lansing (MI).

Boltanski, L., Thévenot, L., 2006 [1st ed. 1991]. On justification: Economies of Worth, Princeton, Princeton University Press.

Brockway, L.H., 1979. Science and C olonial Expansion: The Role of the British Royal Botanic Gardens, New York, Academic Press.

Brockway, L.H., 1988. Plant sciences and colonial expansion: The botanical chess game, in Kloppenburg, J.R., Jr. (Ed.), Seeds and Sovereignty: The Use and Control of Plant Genetic Resources, Durham (NC), Duke University Press, 49-66.

Bromley, D.W., 1998. Transitions to a New Political Economy: Law and Economics Reconsidered, Cambridge (UK), Cambridge University, Department of Land Economy.

Brown, S., Getz, C., 2008. Privatizing farm worker justice: Regulating labor through voluntary certification and labeling, Geoforum, 39, 1184-1196.

Brunstad, R.J., Gaasland, I., Vardal, E., 2005. Multifunctionality of agriculture: An inquiry into the complementarity between landscape preservation and food security, European Review of Agricultural Economics, 32, 469-488.

Busch, L., Bain, C., 2004. New! Improved? The transformation of the global agrifood system, Rural Sociology, 69, 321-346.

Byers, A., Giovannucci, D., Liu, P., 2008. Value-Adding Standards in the North American Food Market: Trade Opportunities in Certified Products for Developing Countries, Rome, Food and Agriculture Organization.

Caswell, M., Day-Rubenstein, K., 2006. Agricultural research and development, in Wiebe, K., Gollehon, N. (Eds), Agricultural Resources and Environmental Indicators, 2006 Edition. Report from the Economic Research Service, USDA, Washington (DC): http://www.ers.usda.gov/publications/ arei/eib16/eib16 _3-2.pdf

Charvolin, F., Joly, P.-B., Boutrais, R., Nuiccolai, G.P., 2008. Connaissances et légitimité dans les espèces hybrides de la recherche, Science et devenir de l'homme, 57-58, 126-141.

Cochrane, W., 1993. The Development of American Agriculture, Minneapolis, University of Minnesota Press.

Comis, D., 1996. Green remediation: Using plants to clean the soil, Journal of Soil and Water Conservation, 51, 184.

Dale, B.E., 2008. Net energy: Still a (mostly) irrelevant, misleading and dangerous metric, Biofuels Bioproducts and Biorefining, 2, 495-496. 
Davis, I., 2005. The biggest contract, The Economist, 375, 8428, 87. Dewey, J., 1927. The Public and Its Problems, New York, Henry Holt.

East, E.M., 1923. Mankind at the Crossroads, New York, Charles Scribner's Sons.

Evans, G.A., 2000. Designer science and the "omic" revolution, Nature Biotechnology, 18, 127.

Frey, K., 1996. National Plant Breeding Study, I. Human and Financial Resources Devoted to Plant Breeding Research and Development in the United States in 1994. Special Report 98, Iowa Agriculture and Home Economics Experiment Station, Ames (IA).

Fulponi, L., 2006. Private voluntary standards in the food system: The perspective of major food retailers, Food Policy, 31, 1-13

Grievink, J.-W., 2003. The changing face of the global food industry. OECD Conference Presentation, The Hague.

Guthman, J., 2007. The Polanyian way? Voluntary food labels as neoliberal governance, Antipode, 39, 3, 456-478.

Hansen, M., Busch, L. Burkhardt, J. Lacy, W., Lacy, L., 1986. Plant breeding and biotechnology: New technologies raise important social questions, BioScience, 36, 29-39.

Harlan, J.R., 1984. Gene centers and gene utilization in American agriculture, in Yeatman, C.W., Kafton, D., Wilkes, G. (Ed.), Plant Genetic Resources: A Conservation Imperative, Boulder (CO), Westview Press, 111-129.

Hendrickson, M., Heffernan, W.D., Howard, P.H., Heffernan, J.B., 2001. Consolidation in food retailing and dairy: Implications for farmers and consumers in a global food system: http: //www.nfu.org/images/heffernan.pdf (accessed 04/13/2002).

IAAKSTD, 2008. International Assessment of Agricultural Knowledge, Science and Technology for Development: http: //agassessment.org/ (accessed 16/12/2008).

Knickel, K., Renting, H., 2000. Methodological and conceptual issues in the study of multifunctionality and rural development, Sociologia Ruralis, 40, 512-528.

Lang, S., 1981. The File, New York, Springer-Verlag.

Levenstein, H., 1988. Revolution at the Table: The Transformation of the American Diet, New York, Oxford University Press.

Liu, P., Boto, I., Kortbech-Olesen, R., Vrolijk, B., Pilkauskas, P. (Eds_). 2001. World Markets for Organic Fruits and Vegetables: Opportunities for Developing Countries in the Production and Export of Organic Horticultural Products, Rome, $\mathrm{FAO} / \mathrm{ITC} / \mathrm{CTA}$.

Lloyd, L.E., Cronier, C., 1989. Dietary guidelines: Implications for agriculture, in Carroll, K.K. (Ed.), Diet, Nutrition, and Health, Montreal, McGill-Queen's University Press.

Macek, T., Macková, M., Kás, J., 2000. Exploitation of plants for the removal of organics in environmental remediation, Biotechnology Advances, 18, 23-34.

Marres, N., 2007. The issues deserve more credit: Pragmatist contributions to the study of public involvement in controversy, Social Studies of Science, 37, 759-780.

Marshall, E., 2005. Will DNA bar codes breathe life into classification?, Science, 307, 1037.

McConnell, G., 1953. The Decline of Agrarian Democracy, Berkeley, University of California Press.

McMichael, A.J., Beaglehole, R., 2000. The changing global context of public health, The Lancet, 356, 495-499.
Middendorf, G., Busch, L., 1997. Inquiry for the public good: Citizen participation in agricultural research, Agriculture and Human Values, 14, 47-57.

Miele, M., 2008. Città slow: Producing slowness against the fast life, Space and Polity, 12, 135-156.

Monteny, G.-J., Bannink, A., Chadwick, D., 2006. Greenhouse gas abatement strategies for animal husbandry, Agriculture, Ecosystems \& Environment, 112, 163-170.

Osborne, M.A., 1982. The system of colonial gardens and the exploitation of French Algeria, 1830-1852, in Fitzgerald, E.P. (Ed.), Proceedings of the Eighth Annual Meeting of the French Colonial Historical Society, Lanham (MD), University Press of America, 160-168.

Perkins, J.H., 1997. Geopolitics and the Green Revolution, New York, Oxford University Press.

Pimentel, D., Patzek, T.W., 2005. Ethanol production using corn, switchgrass, and wood; biodiesel production using soybean and sunflower, Natural Resources Research, 14, 1, 65-76.

Plato, 1994. The Republic [360 B.C.], New York, Vintage Books.

Shiva, V., 1991. The Violence of the Green Revolution, London, Zed Books.

Shukla, J., Nobre, C., Sellers, P., 1990. Amazon deforestation and climate change, Science, 247, 1322-1325.

Stoeckle, M., 2003. Taxonomy, DNA, and the bar code of life, BioScience, 53, 796-797.

Szreter, S., 1993. The idea of demographic transition and the study of fertility change: A critical intellectual history, Population and Development Review, 19, 659-701.

Thompson, P.B., Nardone, A., 1999. Sustainable livestock production: Methodological and ethical challenges, Livestock Production Science, 61, 111-119.

Uauy, R., Albala, C., Kain, J., 2001. Obesity trends in Latin America: Transiting from under- to overweight, The Journal of Nutrition, 131, 893S-899S.

Walzer, M., 1983. Spheres of Justice: A Defense of Pluralism and Equality, New York, Basic Books.

Wheals, A.E., Basso, L.C., Alves, D.M.G., Amorim, H.V., 1999. Fuel ethanol after 25 years, Trends in Biotechnology, 17, 482487.

Wildman, R.E.C. (Ed.), 2001. Handbook of Nutraceuticals and Functional Foods, Boca Raton (FL), CRC Press.

Wolf, S., Zilberman, D. (Eds). 2001. Knowledge Generation and Technical Change: Institutional Innovation in Agriculture, Boston, Kluwer Academic Publishers.

Worster, D., 1979. Dust Bowl: The Southern Plains in the 1930's, New York, Oxford Univesity Press.

Wynne, B., Callon, M., Gonçalves, M.E., Jasanoff, S., Jepsen, M., Joly, P.-B., Konopasek, Z., May, S., Neubauer, C., Rip, A., Siune, K., Stirling, A., Tallacchini, M., Felt, U., 2007. Taking European Knowledge Society Seriously. Report of the Expert Group on Science and Governance to the Science, Economy and Society Directorate, Directorate-General for Research, European Commission, Brussels.

Young, L.R., Nestle, M., 2002. The contribution of expanding portion sizes to the US obesity epidemic, American Journal of Public Health, 92, 246-249.

Reçu le 21 janvier 2009. Accepté le 2 avril 2009. 